\title{
Swot Analysis for Recreational Uses: Niğde Akkaya Dam ${ }^{\#}$
}

\begin{abstract}
Orhun Soydan ${ }^{1, a, *}$
${ }^{1}$ Landscape Architecture Department, Faculty of Architecture, Niğde Ömer Halisdemir University, 51240 Niğde, Turkey *Corresponding author

\begin{tabular}{|c|c|}
\hline A R T I C L E I N F O & A B S T R A C T \\
\hline $\begin{array}{l}\text { "This study was presented as an oral } \\
\text { presentation at the } 5 \text { th International } \\
\text { Anatolian Agriculture, Food, } \\
\text { Environment and Biology Congress } \\
\text { (Tokat, TARGID 2020) } \\
\text { Research Article }\end{array}$ & $\begin{array}{l}\text { The subject of the study is to evaluate the Niğde Akkaya Dam with SWOT analysis and to make } \\
\text { recommendations in terms of recreational use. The aim of the study is to identify the strengths and } \\
\text { weaknesses, threats and opportunities of the Akkaya dam and to determine its goals and strategies } \\
\text { in terms of recreation. In line with this purpose, the socio-economic, cultural and natural features, } \\
\text { landscape potential of the area were evaluated using the SWOT, the opportunities that the positive } \\
\text { and negative aspects of the area, were presented, and the possible or existing threats were } \\
\text { determined. At the same time, the current recreation potential of the dam was determined, and } \\
\text { suggestions were developed in line with the data in order to offer alternatives that can be evaluated } \\
\text { in terms of sustainable use of the areas. It was determined that pollution occurs in the dam water } \\
\text { due to environmental wastes, as a result of this pollution, harmful creatures multiply and bad smells } \\
\text { are formed. However, it is accepted that the dam is home to a large number of migratory birds, that } \\
\text { it has not lost its naturalness, and that most of the dam is in the university campus. Threats to the } \\
\text { dam are; low water level, fishing, duck hunting etc. damage to ecological life due to activities, smell } \\
\text { gradually increased. Their opportunities are determined as providing a suitable environment for bird } \\
\text { watching, having a suitable infrastructure for ecological research, and being suitable for recreational } \\
\text { activities for water. At the end of the study, suggestions were developed in terms of suitability of } \\
\text { Akkaya Dam for recreational activities. }\end{array}$ \\
\hline
\end{tabular}
\end{abstract}

orhunsoydan@ohu.edu.tr (D)https://orcid.org/0000-0003-0723-921X |

(9) () () Te This work is licensed under Creative Commons Attribution 4.0 International License

\section{Introduction}

$80 \%$ of the production in the world occurs in urban areas. In addition, $75 \%$ of those produced are consumed in cities (Swilling et al., 2013). Water is the primary source of natural resources most affected by this consumption (Mariolakas, 2007). Water pressures are increasing, due to pollution, unconscious farming practices and urbanization (Schnoor, 2010). Therefore, it is necessary to use not only quantitative methods but also qualitative methods in determining the damages in the water resources (Hoekstra and Wiedman, 2014). Today, urbanization is developing and growing rapidly (Tucci et al., 2010; Chung et al., 2011; Mori and Yamashita, 2015). Therefore, sustainable development policies become imperative. Industrial and commercial activities in urban areas can be defined as the main factors that put pressure on existing water resources (Brown et al., 2011; Maurya et al., 2020). Lake and wetlands have a great importance in terms of their features, benefits and biodiversity that they contain. In addition, they provide a living space for a wide variety of flora-fauna, and have important functions in hydrological and chemical cycles related to the cleaning of contaminated waters (Elmac1 et al., 2010, Katip et al., 2011, Lai et al., 2012).
Fresh water sources are considered as the natural wealth museums of the region; It is one of the primary ecosystems that must be protected. However, they are the most threatened natural ecosystems. Dams; is currently being evaluated to prevent wasted use of water (Samiotis et al., 2018); In addition, it has high financial and environmental activities for many purposes including electricity production, drought prevention, flood protection, aquaculture, irrigation and water demand (Chowdhury and Al-Zahrani, 2014). The water quality, aquatic species diversity and abundance of a dam lake show significant changes compared to streams. Therefore, it is important to monitor the natural resources of a dam lake formed (Küçükyılmaz et al., 2014). Many studies have been carried out in recent years to determine the water changes occurring in dam lakes and ponds in our country and in the world (Mutlu et al., 2013; Mutlu ve Tepe, 2014; Kutlu et al., 2015; Kurnaz et al., 2016; Mutlu and Uncumusaoğlu, 2017; Tepe and Kutlu, 2019). Some of these studies used SWOT analysis.

In this study, in order to determine the recreational potential of the Akkaya Dam, SWOT Analysis technique 
was used. The SWOT Analysis technique was first used by Heinz Weilrich. SWOT is an analysis method that takes various rational approaches for the determination, planning and sustainability of potential and existing activities. Also, The SWOT Analysis Technique is a research technique that is used to make decisions in the planning and management by determining the current strengths (advantages) and weaknesses (disadvantages) with future priorities and threats (Gürlek, 2002). The word SWOT consists of the initials of the words Strenghts (Weaknesses/ Advantages), Weaknesses (Weaknesses/Disadvantages), Opportunities and Threats. There are two main benefits of SWOT Analysis in planning. Firstly, SWOT Analysis is carried out to determine the strengths and weaknesses, opportunities and threats. In this sense, SWOT is a "current state" analysis. SWOT Analysis is also an analysis or research technique for determining and predicting future situations. In this second sense, SWOT is a "future situation" analysis. In line with these explanations, SWOT Analysis can be perceived as a spectacle providing vision of the current and future (Polat, 2006; Dinç 2020). Güngör and Arslan (2004) used the SWOT method to determine the tourism potential in their study.

Studies on the use of the dams for the recreational activities was investigated. Çelik (2018) investigated for recreational use in Seyhan Dam Lake and its surroundings in Adana. Gök (2011) conducted a study to determine the recreational area usage decisions of the Kozan Dam Lake. Tamcan (2005) carried out studies to reveal the importance of Bayındır Dam Lake and its immediate surroundings in terms of meeting the recreational needs of Ankara city people and to determine the recreational potential of the area in this context. Candranegara et al. (2019) examined Telaga Tunjung Dam for compatibility with ecotourism. Ghernaout and Remini (2020) investigated the Mina River for suitability for recreational activities.

This study which was carried out on Akkaya Dam which is of great importance for the Niğde, will not only add quality to the campus area where it is located in, but it will also provide recreational activities to the local people. The aim of the study is to identify the strengths and weaknesses, threats and opportunities of the Akkaya dam and to determine its goals and strategies in terms of recreation. In line with this purpose, the socio-economic, cultural and natural features of the landscape potential of the area were evaluated using the SWOT, the opportunities that the positive and negative aspects of the area, were presented, and the possible or existing threats were determined. At the same time, the current recreation potential of the dam has been determined and suggestions have been developed in line with the data obtained in order to offer alternatives that can be evaluated in terms of sustainable use of these areas.

\section{Material and Method}

The study area covers the Akkaya Reservoir basin within the borders of the Niğde Turkey. Niğde located in $34^{\circ} 30^{\prime} 10^{\prime \prime}-34^{\circ} 45^{\prime} 00^{\prime \prime}$ eastern longitude and 37 $54^{\prime} 00^{\prime \prime}$ $38^{\circ} 06^{\prime} 30^{\prime \prime}$ northern latitudes. The size of the study area is $580.00 \mathrm{~km}^{2}$ (Figure 1). Akkaya Reservoir Lake where located in the study area, is an irrigation pond formed on the Karasu Stream, which progresses within the city of
Niğde and reaches the Bor Plain (Soydan, 2020). Akkaya Dam was selected as study area both in terms of protecting nature and researching recreational use opportunities that can provide multi-directional benefits for the region. In the study, it was aimed to determine the suitability of the Akkaya Dam in terms of recreational activities. In this context, the relevant literature of the Akkaya Dam was investigated, and field trips were made to determine the current situation. The study was shaped in accordance with the literature reviews and field trip. In line with the information that was obtained from the related units, the current state of Akkaya Dam was analyzed and the properties of the dam were tried to be determined using SWOT analysis. In the study, firstly, the landscape potential of the Akkaya dam was determined. In the second stage, SWOT analysis was used to evaluate this potential in the most suitable way, and their conformity was determined. After determining the SWOT criteria, the criteria were examined by associating them with each other using the SWOT matrix. In SWOT analysis, an analysis is made for the future situation by determining the strengths, weaknesses, opportunities, threats and dangers by considering the current situation. A strategic view for the region can be suggested by researching the analyzes made based on these criteria. The aim of SWOT analysis is to develop new plans and appropriate strategies by taking advantage of the region's strengths and opportunities, reducing threats and identifying weaknesses, taking into account internal and external factors. Finally, suitable recreational activities were suggested for the Akkaya dam.

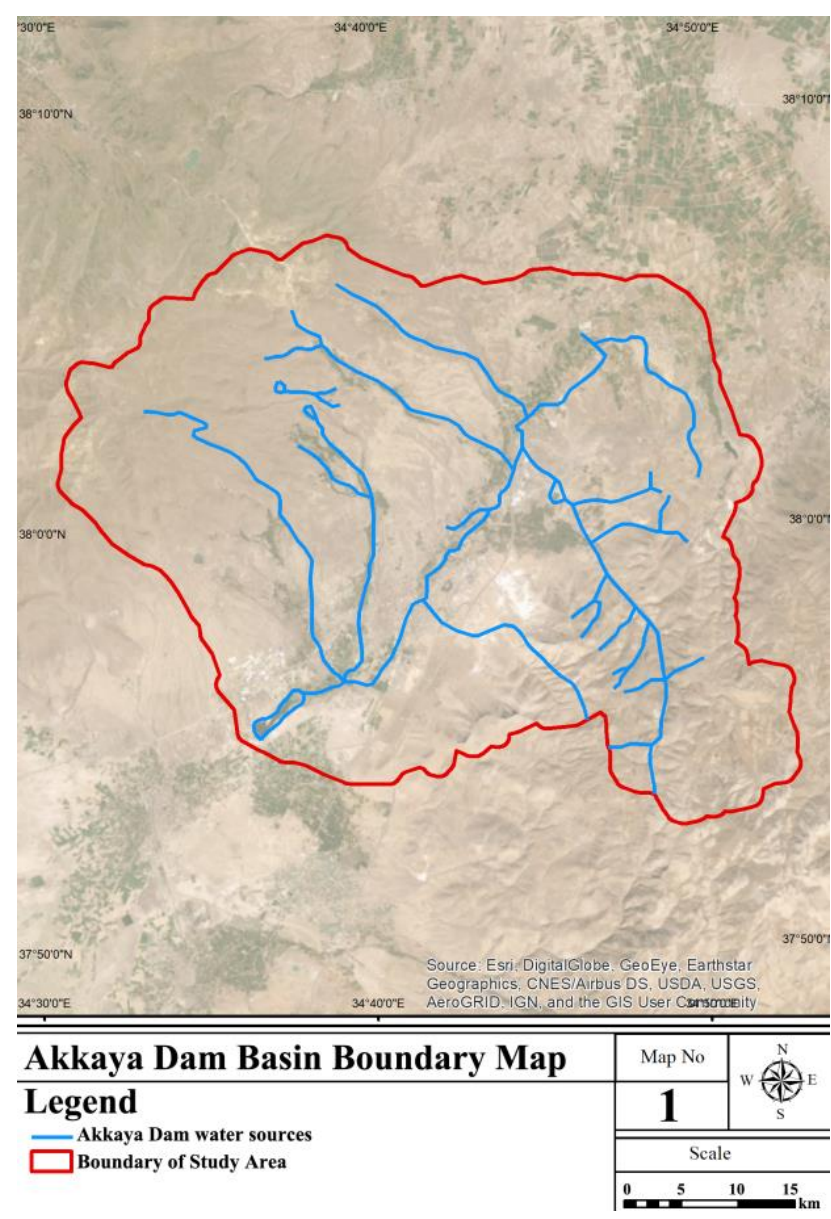

Figure 1. Boundary of study area 


\section{Results and Discussion}

Within the scope of the study, the natural features of the area were determined.

\section{Geological Structure}

Depending on the climatic conditions and bedrock factor, different soil types can be seen in Niğde and its surroundings. Zonal soils which are a ratio of $61.9 \%$, have the widest area among the soil groups which were gathered under 3 groups. This is followed by azonal soils with $37.9 \%$ and intrazonal soils with $0.2 \%$. Brown soils $(2,158$ $\left.\mathrm{km}^{2}\right)$, non-calcareous brown soils $\left(1,198 \mathrm{~km}^{2}\right)$ and zonal, rocky and other areas $\left(1,130 \mathrm{~km}^{2}\right)$ in azonal soils have the largest area in the soil groups (Sever and Kopar 2014). Niğde is located in the central part of the Anatolian land in the Alpine mountain range. The area has various lithological units that similar to mosaic because it is the scene of different geological and geomorphological events by being affected by the internal dynamics (orogenesis, epeirogenesis, block tectonism and volcanism) that shape Anatolia. While the Paleozoic and Mesozoic formations are wider in the southern and eastern part of Niğde, there are volcanic formations in the upper and lower Miocenequaternary regions. There are plutonic and metamorphic rocks in the eastern and southeast of the Niğde (Sever and Kopar 2014). The plains in Niğde are composed of quaternary alluvium, terrestrial clasts carried from the high masses and volcanic sediment.

\section{Soil}

Brown soils have the highest area with $2,158 \mathrm{~km}^{2}$ $(29.90 \%)$ in the study area. Hydromorphic and salinealkali soils are the least area with respectively $8 \mathrm{~km}^{2}$
$(0.10 \%)$ and $5 \mathrm{~km} 2(0.06 \%)$ (Ministry of Agriculture and Forestry 2017) (Table 1). The Niğde province has been one of the important centres where agricultural activities have been carried out throughout history. When the soil structure of Niğde province was examined according to the land use capability classes, $40.38 \%$ (3,147.71 ha) of soils is class VII soils. It is observed that 2,625.77 ha of land which constitutes $33.68 \%$ of the province, consists of lands suitable for cultivation (I. II. III. And IV. Classes) (Sever and Kopar, 2014) (Table 2).

\section{Hydrological Structure}

Due to the high precipitation and the high mountainous areas, Niğde has a wide river network mostly seasonal. Located in the north of the province, Hasan Mountain, Melendiz Mountain, Göllüdağ, Tabur Mountain in the south, Hurç Mountain in the east, Kösedilin Mountain and Pozantı Mountain and the Hışır Mountain in the southwest constitute the main distribution centers of the waters. Niğde has three river basins with different sizes and water potentials. The annual water potential of $763.8 \mathrm{hm}^{3}$ of these basins is provided from the sources within the provincial borders (Olgun, 2018).

Niğde has a total water potential of $1158 \mathrm{hm}^{3}$, of which $763.8 \mathrm{hm}^{3}$ is from above ground water sources, and 394 $\mathrm{hm}^{3}$ is underground water source. There are many streams that differ seasonally in terms of the water potential they carry within the city. Among these streams, Çakıt Creek and Ecemiş Creek are the streams with the highest value in terms of their annual water potential. Although Niğde province is not rich in lakes, it has different lakes in terms of formation and development.

Table 1. The surface area and proportions of soil groups in Niğde (Sever and Kopar, 2014)

\begin{tabular}{|c|c|c|c|c|}
\hline Classification & Soil Groups & Area $\left(\mathrm{km}^{2}\right)$ & Category $\left(\mathrm{km}^{2}\right)$ & Percent $(\%)$ \\
\hline \multirow{5}{*}{ Zonal Soil } & Brown Soil & 2,158 & \multirow{5}{*}{4,566} & \multirow{5}{*}{61.9} \\
\hline & Brown Forest Soil & 671 & & \\
\hline & Non-calcareous Brown Soil & 1,198 & & \\
\hline & Non-calcareous Brown Forest & 529 & & \\
\hline & Terra Sigillata & 10 & & \\
\hline \multirow{2}{*}{ Intraoral Soils } & Hydromorphic Soils & 8 & \multirow{2}{*}{12} & \multirow{2}{*}{0.2} \\
\hline & Saline-Alkali Soils & 5 & & \\
\hline \multirow{4}{*}{ Azonal Soils } & Alluvial Soils & 710 & \multirow{4}{*}{2,787} & \multirow{4}{*}{37.9} \\
\hline & Colluvial Soils & 10 & & \\
\hline & Regosol Soils & 937 & & \\
\hline & Stony Rocky and Other Soils & 1,130 & & \\
\hline Total & & 7,366 & 7,366 & 100.0 \\
\hline
\end{tabular}

Table 2. Land-capability classification of Niğde (Sever and Kopar, 2014)

\begin{tabular}{l|cc}
\hline Land-Capability Classification & Area (ha) & Percent (\%) \\
\hline Class I soils & 456.80 & 5.86 \\
Class II soils & 910.48 & 11.68 \\
Class III soils & 490.32 & 6.29 \\
Class IV soils & 767.83 & 9.85 \\
Class V soils & 17.93 & 0.23 \\
Class VI soils & $1,023.51$ & 13.13 \\
Class VII soils & $3,147.71$ & 40.38 \\
Class III soils & 980.64 & 12.58 \\
Total & $7,795.22$ & 100.00 \\
\hline
\end{tabular}


In particular, there are circus lakes formed by glacial erosion on Aladağlar and Bolkar Mountains. Akgöl, Alagöl, Çinigöl, Yedigöl, Karagöl are the main circus lakes. While volcanic crater lakes are located on Hasan Mountain and Göllü Mountain, Narlı Lake in the north is formed as a result of volcanic depression. These lakes of volcanic origin have the character of brackish water because the lake basins are composed of volcanic rocks. Narlı Lake is a bitter lake besides having mineral rich waters due to feeding underground hot water sources (Olgun, 2018).

\section{Climate}

The typical continental climate of Central Anatolia can be seen in Niğde. In the region where the summers are hot and dry, the winters are cold and snowy, the precipitation is observed in the winter, and the rain in the spring. When the maximum and minimum temperature values of the city of Niğde for 84 years (1935-2019) were examined, it was determined that the highest temperature reached $38.5^{\circ} \mathrm{C}$ in July and August, and the lowest temperature in January with $-25.6{ }^{\circ} \mathrm{C}$. In addition, it is observed that the highest rainfall decreased in May with an average of $48.7 \mathrm{~kg} / \mathrm{m}^{2}$ (General Directorate of Meteorology, 2019).

\section{Vegetation and Wildlife}

As the Niğde is located at the intersection of the Mediterranean and Central Anatolian climates, it has unique features and diversity in terms of vegetation and wildlife. The province has an important wealth in terms of flora and fauna due to its geographical location. These diversity and features are also seen in the studies carried out for the flora and fauna of the province. There are 1200 species in the province of Niğde and 265 of them are endemic (Görür et al. 2016). When the plant species that are located at the park and road sides in the city center of Niğde are examined; There are coniferous plant species such as Cedrus libani, Cupressus sempervirens $L$. horizontalis (Mill.) Gord., Pinus pinea, and non-evergreen plant species such as Fraxinus angustifolia L. and Acer negundo $L$. are found. Also; There are Melia azedarach L., Cupressus sempervirens var. Pyramidalis TargioniTozetti, Robinia pseudoacacia L. var. umbraculifera DC., Platanus orientalis, Aesculus hippocastanum L., Ailanthus altissima (Mill.) Swingle, Morus alba L., Ligustrum japonicum Thunb., Morus alba L. var. pendula Dipp., Cercis siliquastrum L., Populus $x$ canescens (Aiton) Sm., Malus floribunda, Elaeagnus angustifolia species are plant species located in parks and roadsides in the city of Niğde (Erzurumlu and Kahveci 2017).

The Niğde has endemic species in terms of fauna. Taurus frogs that are endemic in Turkey is only known to exist in the lakes of the Kara and Çinli where they located at the top of the Bolkar Mountains within the boundaries of Ulukışla district. Dryomys laniger and a small insectivorous species that are living in Bolkarlar, are among the endemic species of the region. Almost half of 145 species of approximately 160 mammal species in our country, which are terrestrial, have been identified within the borders of the province of Niğde.

In addition, more than half of the 465 bird species found in our country were found within the provincial borders of Nigde (Ministry of Agriculture and Forestry 2013).
Akkaya Dam Lake and its surroundings in the study area is an important area in terms of biodiversity. Oxyura leucocephala, which is effective in declaring the area as an International Wetland, lives and nests in this area. There are also two endemic fish species (Pseudophoxinus anatolicus and Aphanius anatoliae) in the reservoir. This area has important bird areas and important nature areas. Apart from these, it hosts approximately 200 bird species including various heron, flamingo, pelican and various duck species, and 33 endemic plant species increase the importance of the area (Başköse et al. 2012).

\section{Akkaya Dam}

Akkaya reservoir lake area was built as a total of $1.40 \mathrm{~km}^{2}$ in 1965. Water surface maps produced with MNDWI were prepared for the summer months of 1999, 2009 and 2019 years. The water surface area covered by the reservoir area changed each year. The highest water surface area in the reservoir lake was 2019 year. The year in which the reservoir lake surface was the least was found to be 1965 which is reservoir was built considering the reference surface area in other years, an average increase of $37 \%$ was found in the reservoir lake water surface area (Soydan, 2020).

\section{Akkaya Dam SWOT Analysis}

Akkaya Dam is of great importance for the province of Niğde. Its natural and cultural features also contribute to the dam in terms of urban use. However, the dam faces many problems and threats, especially pollution.

Eliminating the problems for this and solving the problems found in the dam area will provide benefits in terms of recreational uses. Akkaya Dam SWOT Analysis was given Table 3 . Photos that were taken from the area are given in Figure 2. As a result of the analyzes, the biggest problem in the dam was found to be bad smell. In addition, environmental pollution in the dam and its vicinity causes problems. The strongest part of the dam is its endemic species. Especially there are endemic bird species that allow the dam to be identified as a protection area. However, the number of these birds will start to decrease in time due to reasons such as poaching and environmental pollution. At the end of this, bird watching, which has a great importance in terms of recreational activity, will not be possible. It is located in the vicinity of Niğde Province in an area where tourism activities are intensive such as Kayseri, Nevşehir and Adana. In these areas, recreational activities such as skiing, water activities and underground cities are carried out. For this reason, Niğde Province is a bit behind in terms of tourism compared to these cities.

This reduces the reason why Niğde is preferred. Therefore, by protecting and planning such natural structures, the region can also be developed economically. Similar results were obtained in other studies. Çelik (2018) stated that there are environmental pollution problems in the Seyhan dam and that the dam will be preferred more in terms of recreational activities by solving these problems. Gök (2011) stated that the Kozan Dam lake and its immediate surroundings are particularly suitable for recreational activities, but there are environmental problems. Bulut and Ceyhan (2011) stated that the biggest problem is bad smell in their study on the artificial lakes of Niğde region. 
Table 3. SWOT analysis of Akkaya Dam

\begin{tabular}{ll}
\hline \multicolumn{1}{c}{ Strengths } & \multicolumn{1}{c}{ Weaknesses } \\
\hline $\begin{array}{l}\text { It contains a strong and large flora and fauna. } \\
\text { Endemic plant species }\end{array}$ & Bad Smell \\
$\begin{array}{l}\text { Endemic bird species } \\
\text { Endemic fish species }\end{array}$ & Lack of publicity \\
Compliance with recreational activities & Lack of incentives \\
Compliance with organic farming practices & Insufficient tourism \\
Accessibility & The majority of the dam is located within the campus \\
Being natural or close to nature & and is not open to the public. \\
\hline \multicolumn{1}{c}{ Opportunities } & \\
\hline Compliance with recreational activities & \\
Compliance with organic agriculture & Threats \\
Increased interest to nature & Increased pollution of water \\
Alternative tourism activities & Increased bad smell \\
Contributing to the local economy through activities & Environment pollution \\
New job opportunities & Poaching \\
Endemic Species & Changes in the Physical and Chemical Properties of \\
& Water \\
& Prevention of Reproduction of Pests and Harmful \\
& Creatures \\
& Threatening Live Life in the Receiving Environment \\
& Financial Impossibilities \\
\hline & Shortage of Staff \\
\hline & Treatment Facilities Not Running Regularly \\
\hline
\end{tabular}

While the sewage is poured into the Akkaya Dam by mixing with the natural water in the Niğde Stream, the sewage pipes were laid in the stream recently (8-10 years), and the channel water was separated from the natural water of the Niğde Stream. Niğde sewage wastes pass through the Niğde River bed with these pipes and enter the Niğde Municipality Treatment Facilities before reaching the dam. Waste water is sent to Akkaya Dam after passing this facility. Although sewage water is said to be treated at the treatment plant, it is an indisputable fact that it cannot be as much as the cleaning of natural water.

This situation may threaten the life of these creatures by causing the lake's fish and bird species to suffer from pollution. Apart from these creatures, the main problem is the use of dam waters in the vineyard and garden irrigation of Bor City. As a matter of fact, the fact that the Akkaya Dam water is in the first place among the agricultural problems of Bor Tarım District Directorate shows that water poses a risk for public health. Dam waters that are polluted by many waste materials, affect the fauna species in the lake. It was stated verbally by the researches that there were fish poisonings in the past years due to the heavy metal pollution formed in the dam as a result of the wastes of the Niğde Organized Industry located in the north of the dam. it was also stated in the 2010 report of the related Ministry that this wastewater made changes in the physical and chemical properties of Akkaya Dam water. These changes in the water have also been noticed by the local community. It was observed that excessive green foams were formed inside the water channels coming from the dam. It is stated that channel waters cause some problems such as low productivity in agricultural production, drying of vegetables and even death. There is a water pollution problem in the streams feeding the local dams of the Niğde and Bor. As a matter of fact, according to the results of the Ministry of Environment and Forestry, it has been determined that the primary priority problem in Niğde is water pollution. Some difficulties were encountered in eliminating these water problems in the region. Although these difficulties were identified, it was also stated in the Akkaya Dam Lake and Environmental Problems Workshop that rational measures were not taken to eliminate deficiencies, ecological problems were increasing day by day, and flora and fauna species were negatively affected by this situation. Apart from ecological problems, the illegal network shot in the dam constitutes another problem. Inadequate controls cause both netting and hunting of rich bird species, especially duck in the lake (Bulut and Ceylan, 2011). Despite all these adversities, the problems in the dam and its immediate vicinity can be minimized by the restoration works to be carried out. In this way, it will be possible to protect the dam ecologically and also include new recreational activities.

\section{Conclusion}

Cities with environmental problems are increasing rapidly in our country. On the one hand, cities undergo a significant change with the slums formed by the population flow from rural areas, on the other hand, with large and multi-storey buildings and industrial establishments. In cities where ecological relations are ignored, as a result of the gradual decrease in natural areas, climate and soil conditions are changing, and besides, an artificial living environment is created with harmful substances originating from housing, industry and vehicles. There was not a complete harmony between the living conditions in this artificial city ecosystem and the environment that people seek and long for, causing excessive population growth, air pollution, noise, fatigue and psycho-physiological imbalances in humans. Therefore, people's desire to change the environment pushes them out of the city. In order for people to rest, have fun and renew their minds; forested areas, water and water edges have a very important potential due to their recreational features. 


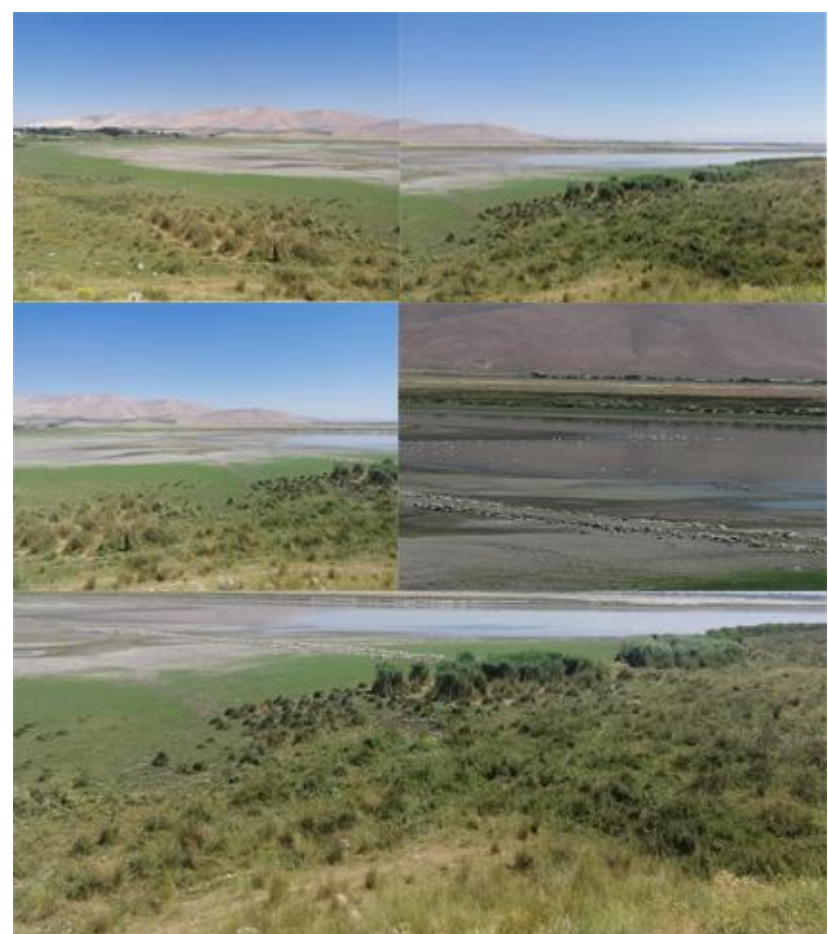

Figure 2. Photos from the study area

Recreation areas have a phenomenon that reflects the image, shape, culture and economy of the city and the country. Therefore, recreation area uses, designs and plans should be formed as a result of very good analysis. If careful planning and designs are not made, large losses and false image perception are created (Gök, 2011). Akkaya Dam Lake has a great potential in terms of recreation. Investments planned to be made in the area should be handled in a way that will have tourism and recreational activities and demands, taking into account the natural, cultural and social structure of the region.

Most importantly, in order for the natural existence of the area to be less damaged, it should be done in accordance with the coastline and wildlife development area. As a result of the analyzes, recreational activities for water that can be performed in Akkaya and its immediate surroundings, are as follows; Swimming, Underwater dives, Bottling, Shovel, Sailing, Water skiing, Angling, Walking, Camping, Picnic, Ride a bike etc. Recreational activities that can be performed according to the natural features of the dam are as follows; Bird watching, Organic agriculture, Plant Production and Protection Areas, Herbarium, Ecology Observation Points.

Problems such as fishing by netting, hunting duck and other bird species are seen in Akkaya Dam. In order to prevent fish and bird catches that are smuggled, a staff assigned to poaching should be allocated by the municipality. Thus, the birds, which are limited in number in the world and in our country, will be preserved and the fish will not be exhausted. Landscape arrangements such as asphalting the dirt road of the Akkaya Dam, which is entered over the Niğde-Bor highway, pavement, lighting, planting trees on the roads, should be made to evaluate this area for recreational activities. Alternative tourism possibilities of this wetland should be increased by opening up to 194 bird species nature eco-tourism and bird watching in Akkaya wetlands. Besides, sewage waters that are coming to the dam, should be prevented. Although sewage water reaches the dam after the treatment facilities, it causes pollution. Environmental pollution that are occurring in the dam and its vicinity, should be prevented. In this way, living things in the dam and its vicinity will have more living spaces. The use of the dam in terms of agricultural activities should be limited. As a result of agricultural activities, dam water decreases, and heavy metals occur in the dam due to pesticides. Contribution will be made to the ecological cycle of living things in the dam by preventing this. More attention should be given to the promotion of the region. Only the works to be carried out in the Akkaya dam and its immediate surroundings will not be sufficient.

In order to make the area more preferred, the city of Niğde should have more tourism activities. As a result of the study, it was determined that there are problems at the Akkaya dam, but there are more opportunities than the threats. Accordingly, the weaknesses and threats should be reduced, and the use of the dam in terms of recreational activities should be ensured. Besides, the strengths and opportunities of the dam should be considered, and decisions should be made accordingly.

\section{References}

Başköse İ, Paksoy MY, Savran A. 2012. The flora of Nigde University campus environment and Akkaya Lake Dam (Nigde / Turkey). Biological Diversity and Conservation, 5 (3): 82-97.

Brown R, Ashley R, Farrelly M. 2011. Political and professional agency entrapment: an agenda for urban water research. Water Resources Management, 25(15): 4037-4050.

Bulut İ, Ceylan S. 2011. Artificial lakes of the Niğde region with its ecological problems and functions. Atatürk University Journal of Social Sciences Institute, 15 (2): 263-288.

Candranegara IMW, Mirt IW, Suryana INM, Mahardhika IPE. 2019. Pemberdayaan Masyarakat dan Pengelolaan Ekowisata D'Bendungan View Telaga Tunjung Sebagai Wahana Rekreasi Wisata Alam Pedesaan. Public Inspiration: Jurnal Administrasi Publik, 4(2): 97-104.

Chowdhury S, Al-Zahrani M. 2014. Water quality change in dam reservoir and shallow aquifer: analysis on trend, seasonal variability and data reduction. Environmental monitoring and assessment, 186(10): 6127-6143.

Chung ES, Hong WP, Lee KS, Burian SJ. 2011. Integrated use of a continuous simulation model and multi-attribute decisionmaking for ranking urban watershed management alternatives. Water resources management, 25(2): 641-659.

Çelik M. 2018. Evaluation of Seyhan Dam Lake and Its environment in Terms of Recreational Use. Süleyman Demirel University Graduate School of Natural and Applied Sciences Department of Landscape Architecture, Master Thesis, 146p

Dinç C. 2020. Evaluation of Rural Tourism Potential of Van Ili Gevaş District. Artvin Coruh University, Institute of Science, Landscape Architecture Department, Master's Thesis, 89s.

Elmaci A, Topaç FO, Teksoy A, Özengin N, Başkaya HS. 2010. Evaluation of Physicochemical Characteristics of Lake Uluabat in Accordance with Guidelines. Uludağ University Journal of The Faculty of Engineering, 15(1).

Erzurumlu GS, Kahveci B. 2017. The Assessment of Niğde Ömer Halisdemir Campus with Regards to Landscape Quality. Scholars Bulletin, 3(12): 718-726.

Ghernaout R, Remini B. 2014. Impact of suspended sediment load on the silting of SMBA reservoir (Algeria). Environmental earth sciences, 72(3): 915-929. 
General Directorate of Meteorology. 2019. Chart of Antalya City rainfall intensity over time. Ankara: Republic of Turkey, Ministry of Agriculture and Forestry, General Directorate of Meteorology.

Gök Y. 2011. The Recreational Usage Area of Kozan Dam Lake and Its Surroundings. Çukurova University Institute of Natural and Applied Sciences Department Of Landscape Architecture, Master Thesis, 134p.

Görür A, Doğan S, Çalışkan ME, Ünal E, Türkmen HH. 2016. Niğde Province Development Plan (NİGEP). Ahiler Development Agency, Niğde, 638 p.

Güngör S, Arslan M. 2004. Swot Analysis for Tourism and Recreation Strategies, Visual Quality Assessment, Appreciation of Tourism Facilities and Condition Analysis of Tourism Facilities: Beyşehir District Example. Selcuk Journal of Agriculture and Food Sciences, 18 (33): 68-72.

Gürlek TB. 2002. SWOT Analysis. Scientific and Technical Research Council of Turkey, TÜSSIDE June, 10p.

Hoekstra AY. Wiedmann TO. 2014. Humanity's unsustainable environmental footprint. Science, 344(6188): 1114-1117.

Katip A, Karaer F, Başkaya HS, Ileri S, Sarmaşik S. 2012. Fraction distribution and risk assessment of heavy metals and trace elements in sediments of Lake Uluabat. Environmental Monitoring and Assessment, 184(9): 5399-5413.

Kurnaz A, Mutlu E, Aydın Uncumusaoğlu A. 2016. Determination of Water Quality Parameters and Heavy Metal Content in Surface Water of Çiğdem Pond (Kastamonu/Turkey). Turkish Journal of Agriculture - Food Science and Technology, 4(10): 907-913.

Kutlu B, Sesli A, Tepe R, Mutlu E. 2015. Assessment of physicochemical water quality of birecik dam, Şanlıurfa, west east region, turkey. Turkish Journal of Agriculture-Food Science and Technology, 3(7): 623-628.

Küçükyılmaz M, Örnekci GN, Özbey N, Şeker T, Birici N, Yıldız N, Koçer MAT. 2014. Işıktepe Baraj Gölü (Maden, Elazığ) Kıyı Bölgesi Fizikokimyasal Su Kalitesi Üzerine İlk Bulgular. Yunus Araştırma Bülteni, 2: 55-63.

Lai XJ, Huang Q, Jiang JH. 2012. Wetland inundation modeling of Dongting Lake using two dimensional hydrodynamic model on unstructured grids. Procedia Environmental Sciences, 13: $1091-1098$.

Maurya SP, Singh PK, Ohri A, Singh R. 2020. Identification of indicators for sustainable urban water development planning. Ecological Indicators, 108, 105691.

Ministry of Agriculture and Forestry. 2013. Ecotourism Action Plan for Diversification of Niğde Tourism 2013-2023. Ministry of Forestry and Water Affairs Publications, Ankara, $80 \mathrm{p}$.

Ministry of Agriculture and Forestry. 2017. 1/25 000 scale national soil database

Mutlu E, Aydın Uncumusaoğlu, A. 2016. Physicochemical analysis of water quality of Brook Kuruçay. Turkish Journal of Agriculture - Food Science and Technology, 4(11): 991 998.
Mori K, Yamashita T. 2015. Methodological framework of sustainability assessment in City Sustainability Index (CSI): A concept of constraint and maximization indicators. Habitat International, 45: 10-14.

Mutlu E, Yanık T, Demır T. 2013. Horohon Deresi (Hafik- Sivas) su kalitesi özelliklerinin aylık değişimleri. Alınteri Zirai Bilimleri Dergisi 25 (B): 45.

Mutlu E, Tepe AY. 2014. Yayladağı Sulama Göleti (Hatay) Suyunun Bazı Fiziksel ve Kimyasal Özelliklerinin İncelenmesi. Alinteri Journal of Agriculture Sciences, 27(2): 18-23

Olgun R. 2018. Determination of Strategic Objectives and Development to Planning Strategies Open and Green Spaces of Niğde. Akdeniz University, Landscape Architecture Department Doctoral Thesis, Antalya, Turkey, $320 \mathrm{p}$.

Polat AT, Önder S. 2006. A Research on the Evaluation of Landscape Properties of Karapınar District and Its Vicinity in Terms of Ecotourism Use. Selcuk University Faculty of Agriculture Journal 20 (40): (2006) 53-64.

Samiotis G, Trikoilidou E, Tsikritzis L, Amanatidou E. 2018. Comparative water quality assessment between a young and a stabilized hydroelectric reservoir in Aliakmon River, Greece. Environmental monitoring and assessment, 190(4): 234.

Schnoor JL. 2010. Water sustainability in a changing world. National Water Research Institute, Open Humanities Press, $21 \mathrm{p}$.

Sever R, Kopar İ. 2014. Geographical Features of Niğde. Niğde Governorate Provincial Directorate of Culture and Tourism, Niğde, $180 \mathrm{p}$.

Soydan O. 2020. Determination of Water Surface and Vegetation Change in Akkaya Reservoir Basin Using Remote Sensing Method. Turkish Journal of Agriculture-Food Science and Technology, 8(5): 1174-1180.

Swilling M, Robinson B, Marvin S, Hodson M. 2013. City-level decoupling Urban resource flows and the governance of infrastructure transitions. United Nations Environment Programme (UNEP): A report of the working group on cities of the international resource panel.

Tamcam S. 2005. The Examination of The Bayındır Dam Lake and The Recreational Usage of Its Close Environment. Ankara University, Graduate School of Natural and Applied Sciences, Landscape Architecture Deparmenti Master Thesis, $150 \mathrm{p}$

Tepe R, Kutlu B. 2019. Examination Water Quality of Karkamış Dam Lake. Turkish Journal of Agriculture-Food Science and Technology, 7(3): 458-466.

Tucci C, Parkinson JN, Goldenfum JA. 2010. Integrated Urban Water Management: Humid Tropics: UNESCO-IHP (Vol. 6). CRC Press. 